\title{
Ultrastructural observations on feeding appendages and gills of Alvinella pompejana (Annelida, Polychaeta)
}

\author{
V. Storch ${ }^{1} \&$ F. Gaill ${ }^{2}$ \\ ${ }^{1}$ Zoologisches Institut I (Morphologie/Ökologie); Im Neuenheimer Feld 230, D-6900 \\ Heidelberg, Federal Republic of Germany \\ ${ }^{2}$ Centre de Biologie Cellulaire; 67, rue Maurice Günsbourg, F-94200 Ivry sur Seine, \\ France
}

\begin{abstract}
The feeding appendages of Alvinella pompejana obtained from a deep-sea hydrothermal vent environment are described. They are characterized by a ciliated groove, the cells of which have a very distinctive ultrastructure, by groups of bipolar receptor cells and by several kinds of gland cells. Among these, one cell type is in an upside down position suggesting a function completely different from other epidermal secretory cells. The gills differ considerably from the feeding appendages on the basis of their ultrastructure. Their epidermis is very irregular in height; basal infoldings give the blood access to a space coming very near to the external medium. The blood vascular system is open. On the other hand, the gills of Amphicteis gunneri are not effective sites of gas exchange, since their columnar epithelium is underlain with muscle cells. The cells composing the feeding appendages and gills of Alvinella pompejana are characterized by ultrastructurally very different mitochondria.
\end{abstract}

\section{INTRODUCTION}

Ampharetidae is a family of tube-dwelling polychaetes related to Terebellidae and Amphictenidae. They comprise over two hundred described species and are well represented in deep waters where food is scarce. Some years ago, a new species, Alvinella pompejana, was described by Desbruyères \& Laubier (1980) from the immediate vicinity of the warm hydrothermal springs east of the Galapagos Islands. As in other representatives of the family, the anterior body region carries numerous feeding appendages which presumably can be withdrawn completely into the mouth cavity into the roof of which they are inserted. Additionally, the anterior segments bear four pairs of branchiae composed of a stem and many filaments and arranged in lateral groups.

In the meantime, six species and subspecies of the recently erected subfamily Alvinellinae have been described. Desbruyères \& Laubier (in prep.) supposed that these are well separated from all other terebellomorph polychaetes due to the absence of a clear differentiation between thorax and abdomen, a character justifying the proposal of a new family, Alvinellidae. All of them are strictly associated with deep hydrothermal vents. Among them, A. pompejana, is the most thermophilous species of invertebrates currently known from this biotope. It can tolerate temperatures from 20 to $40^{\circ} \mathrm{C}$ (Laubier \& Desbruyères, 1985; Desbruyères et al., 1985).

Most Ampharetidae are considered surface deposit-feeders (for literature see 
Fauchald \& Jumars, 1979). They stretch out of their tube spreading their tentacles over the substratum, and keep their branchiae up in the water. It is not certain whether the same is true of the above-mentioned species of hydrothermal vents. Electron microscopic analysis of $A$. pompejana has demonstrated the presence of coccoid and filamentous bacteria on various areas of their integument (Desbruyères et al., 1983). The microorganisms are especially numerous in the dorsal part of the body and on the posterior parapodia. Gaill et al. (1984a) were able to find them in four types of integumental associations. The functional significance of the epibiotic bacteria, however, is still an enigma. Alayse-Danet et al. (1985) suggest that some metabolite exchange between the microorganisms and their animal host occurs. Whereas the surface specializations of the posterior region and the tube have been analysed by transmission and scanning electron microscopy and microprobe analysis by several authors (Alayse-Danet et al., 1985; Desbruyères et al., 1983; Gaill et al., 1984b; Laubier et al., 1983; Vovelle \& Gaill, 1986), investigations on the feeding appendages and gills are lacking, not only for this species, but for the whole family. Feeding tentacles of the related Lanice conchilega (Terebellidae) have been analysed ultrastructurally by Schulte \& Riehl (1976); gills of various species, including Terebellidae and Amphictenidae, have been investigated by Storch \& Alberti (1978) and by Menendez et al. (1984). Receptor cells on the body appendages
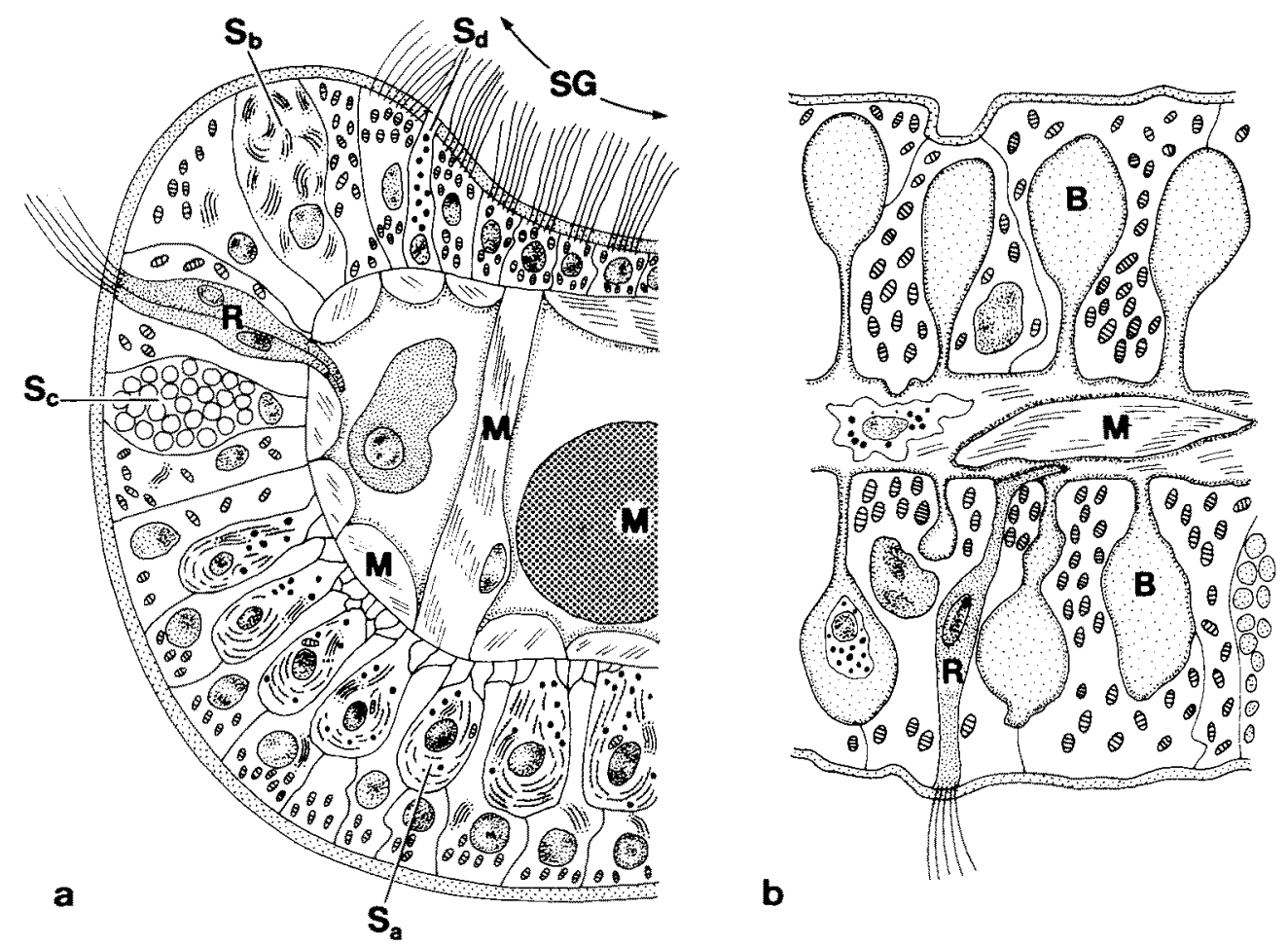

Fig. 1. Alvinella pompejana. Schematic representation of feeding appendage ( $a$, cross section) and gill filament (b). B: blood space in gill, $\mathrm{M}$ : muscle cell, $\mathrm{R}$ : receptor cell, $\mathrm{S}_{\mathrm{a}-\mathrm{d}}$ : secretory cells, SG: ciliated groove 
were analysed, e.g. by Boilly-Marer (1972), Dorsett \& Hyde (1969), Lawry (1967), Michel (1970), Storch (1972). Findings on Ampharetidae are lacking. Mucous cells have been investigated by Bielakoff et al. (1975), Dorsett \& Hyde (1969), Hausmann (1982), Hilbig (1986), Kryvi (1972), Martin (1978), Storch \& Welsch (1972), again excluding the aforementioned family.

Since the external appearance of gills varies widely within the family Ampharetidae (and within Alvinellinae/Alvinellidae), a second species having smooth branchiae, Amphicteis gunneri, was sectioned for comparison in this study.

\section{MATERIAL AND METHODS}

Alvinella pompejana was collected at a depth of $2600 \mathrm{~m}$ at $12^{\circ} 48^{\prime} \mathrm{N}$ and $103^{\circ} 56^{\prime} \mathrm{W}$ by the research submersible "Cyana". After retrieval to the surface, small pieces of the animals were fixed with 0.4 cacodylate-buffered glutaraldehyde $(3 \%$ final concentration) at $\mathrm{pH} 7.2$ and then post-fixed with osmium tetroxide ( $1 \%$ final concentration). The material was embedded in Durcopan.

Amphicteis gunneri was collected in the Kattegat by the research vessel "Poseidon ". Pieces were immersed in ice-cold glutaraldehyde $(3.5 \%$ in phosphate buffer, $\mathrm{pH} 7.5)$. After post-fixation with $1 \%$ osmium tetroxide, the tissue was dehydrated in ethanol and embedded in Araldite.

Thin sections were stained for 5 min with uranyl acetate (saturated solution in $70 \%$ methanol) and for a further $5 \mathrm{~min}$ in lead citrate (Reynolds, 1963). The sections were examined in a Zeiss EM 9-S2 and Zeiss EM $10 \mathrm{C}$ microscope.

\section{RESULTS}

\section{Feeding appendages}

The feeding appendages of Alvinella pompejana are retractile and filamentous. Their subepidermal core contains a complicated musculature whose major constituents are longitudinal muscle cells in the centre and transverse muscle cells that link a ciliated area with the opposite side (Fig.1a). Additionally, there are oblique muscle cells and muscle cells spanning the inner and outer edges of the groove. The framework of the muscle cells may be filled with amebocytes, rather homogeneous blood cells (Fig. $5 \mathrm{~d}$ ) and by single hat-shaped cells which cannot be interpreted with certainty from our limited material. Their condensed nucleus which is associated with mitochondria suggests that they could represent extremely modified sperm cells. Since these polychaetes successfully occupy the extreme habitats of the hydrothermal vents, direct transfer of (modified) sperm cells seems plausible. Immediately below the epidermis, collagen fibrils can be found. The ciliated area occupies nearly one half of a cross-section. Normally it is concave forming a longitudinal groove. The whole of the tentacle epidermis is provided with secretory cells belonging to several types. The cuticle of these appendages is relatively thin $(1-2 \mu \mathrm{m})$, penetrated by numerous microvilli and covered by typical epicuticular projections (Fig. $2 a$, b). Often, the fibrils follow a sinusoidal path (Fig. 2a). In the ciliated groove the shape of the cells ranges from flat (in the centre) to prismatic (in the marginal position). Their cilia are constantly of the 

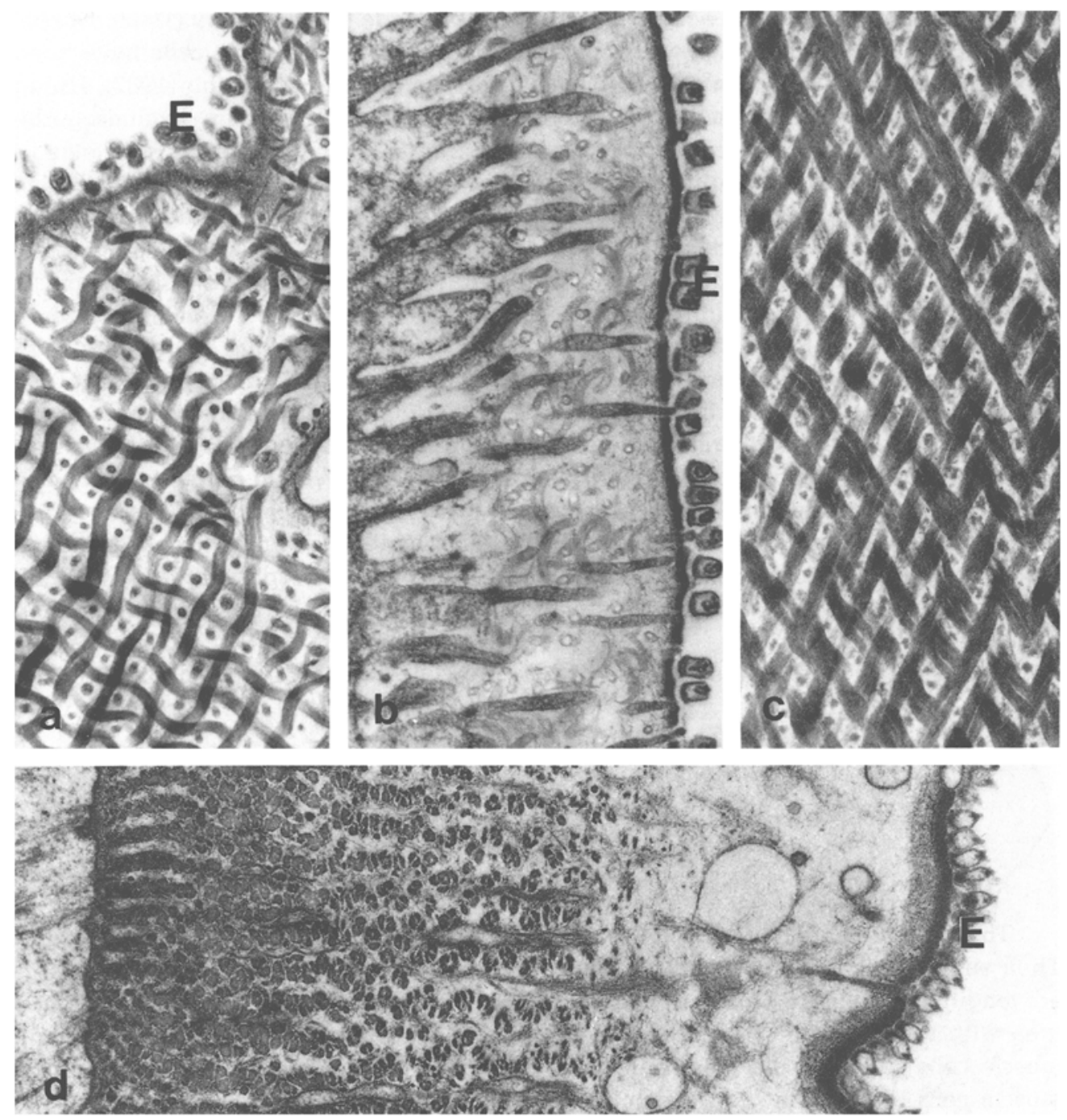

Fig. 2. Alvinella pompejana (a-c) and Amphicteis gunneri (d), cuticle. E: epicuticular projections. a Tangential section of feeding tentacle $(19000: 1) ; b$ cross section of feeding tentacle $(19000: 1) ; c$ tangential section of stem of gill (19 000:1); $d$ cross section of gill of Amphicteis gunneri (19 000: 1)

conventional $9+2$ formula. Their rootlets are inserted at an angle of about $45^{\circ}$ to the surface (Fig. $3 \mathrm{a}-\mathrm{c}$ ) and are arranged more or less parallel to one another. The adjacent cytoplasm is dominated by a dense population of mitochondria with a very distinctive ultrastructure (Fig. 3d). Their cristae are often longitudinally arranged, sometimes in zigzag orientation. Another accumulation of mitochondria of the same type can be found in the basal portion of these cells, whereas the round nucleus is located centrally, often surrounded by some dictyosomes and bundles of filaments. Outside the ciliated groove; supportive cells, secretory and receptor cells dominate. 



Fig. 3. Alvinella pompejana. Ciliated groove (a-d) and gill (e). M: subepidermal muscle cell, R: rootlets of cilia, $S_{c}$ and $S_{d}$ : secretory cells. a Low power micrograph of ciliated groove (2400:1); $b$ Cuticle, basal bodies and ciliary rootlets $(R)(9500: 1) ; c$ Ciliary rootlets and secretory cell $\left(S_{c}\right)(9500$ : 1); d mitochondria of ciliated cells in groove (19 000: 1); e mitochondria of gill epithelium (19 000:1) 
The supportive cells are prismatic, but have an irregular outline, which is due to their neighbouring cells (see below). Their nucleus is elongated, and in a central position. Apically, these cells have many dark mitochondria, which differ considerably from the aforementioned mitochondria of the ciliated cells (Fig. 5c). Dictyosomes composed of about 10 cisternae, single cisternae of the rough endoplasmic reticulum, longitudinally arranged bundles of filaments, and vesicles of different sizes commonly occur in the cytoplasm.

Secretory cells can be classified as follows:

(a) In this common cell type the rough endoplasmic reticulum is arranged as cisternae and occupies most areas of the cytoplasm (Fig. $4 \mathrm{a}-\mathrm{C}$ ). Dictyosomes are arranged in the vicinity of the central cell nucleus. The secretory products are electron dense and globular. The mitochondria are large and dark; again these organelles differ from that previously described. If the bulk of the secretory products were not located basally, and if these cells had an opening into the cuticular face of the integument, then the ultrastructure of this cell type would correspond to a widespread cell type within marine invertebrates (Storch \& Welsch, 1972).

In fact, these cells were never found to reach the apical surface of the epithelium.

(b) The cytoplasm of this cell type is dominated by the secretory product and Golgi fields which are characterized by electron-lucent and alternating electron-dense areas (Fig. $4 \mathrm{~d}$, e). The general outline of these cells is very irregular. The round nucleus is located in the lower third.

(c) Another cell type contains globular secretory droplets which are packed close together. Electron-dense dots are distributed all over the secretion, which is of medium electron-density (Fig. 3c). The nucleus is located basally, the secretory product is the predominant feature of the cell.

(d) This cell type is slender; its cell body can be located in the sub-epithelial tissue extending a process to the surface. The nucleus occupies a basal or lateral position and is surrounded by a rim of cytoplasm. The distal part of the cell is dominated by electrondense secretory droplets.

Groups of about six interspersed slender bipolar cells with apical cilia (about 10 per cell) can be found. The cilia traverse the cuticle (Fig. $5 a$, b) and are of the ordinary $9+2$ pattern. Below their basal bodies many mitochondria occur (Fig. 5b), which are less dense than those of the supportive cells. In the immediate vicinity of the receptor cell aggregations, a single secretory cell with a very light secretion occurs (Fig. 5b). Nerve cell processes can be found in a basiepithelial position.

\section{Gills}

The gills differ considerably from the feeding appendages. This applies to their shape and to their ultrastructure. They are pinnate, bearing very many thin outgrowths. Their cuticle is thick $(5 \mu \mathrm{m})$ in their central stem (Fig. $2 \mathrm{c})$, but extremely thin $(0.5 \mu \mathrm{m})$ in the pinnules (Fig. 1b). The cuticle of the stem is similar to the one described from the dorsal side of the body (Gaill \& Bouligand, 1985). Fibrils are aligned along right-handed or left-handed helices around the organ. Ultrastructurally, they resemble the gills of Terebellides as described by Storch \& Alberti (1978), which means that their epidermis is very irregular, infolded in circumscribed areas giving the blood access to a space coming 

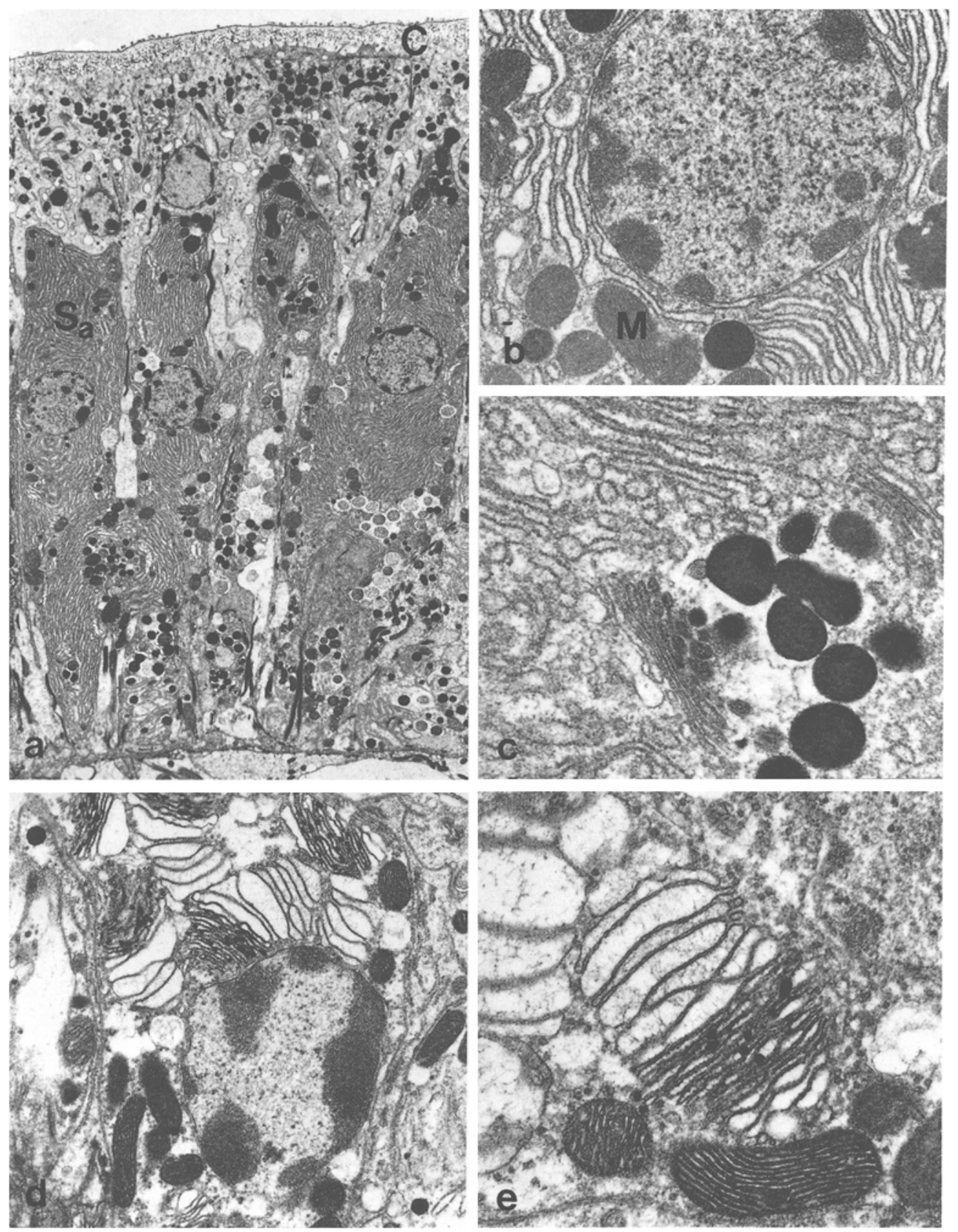

Fig. 4. Alvinella pompejana. Secretory cells. C: cuticle, M: mitochondrium, $\mathrm{S}_{\mathrm{a}}$ : secretory cell a. a-C Secretory cell type $a_{i} d$, e secretory cell type b. a Low power micrograph of secretory cells and supportive cells (2400: 1); $b$ nucleus, surrounding endoplasmic reticulum, and mitochondria (M) (9500: 1); $c$ endoplasmic reticulum, dictyosome, and secretory droplets $(19000 ; 1) ; d$ nucleus and surrounding cytoplasm (9500: 1); e dictyosome and mitochondria (19000: 1) 

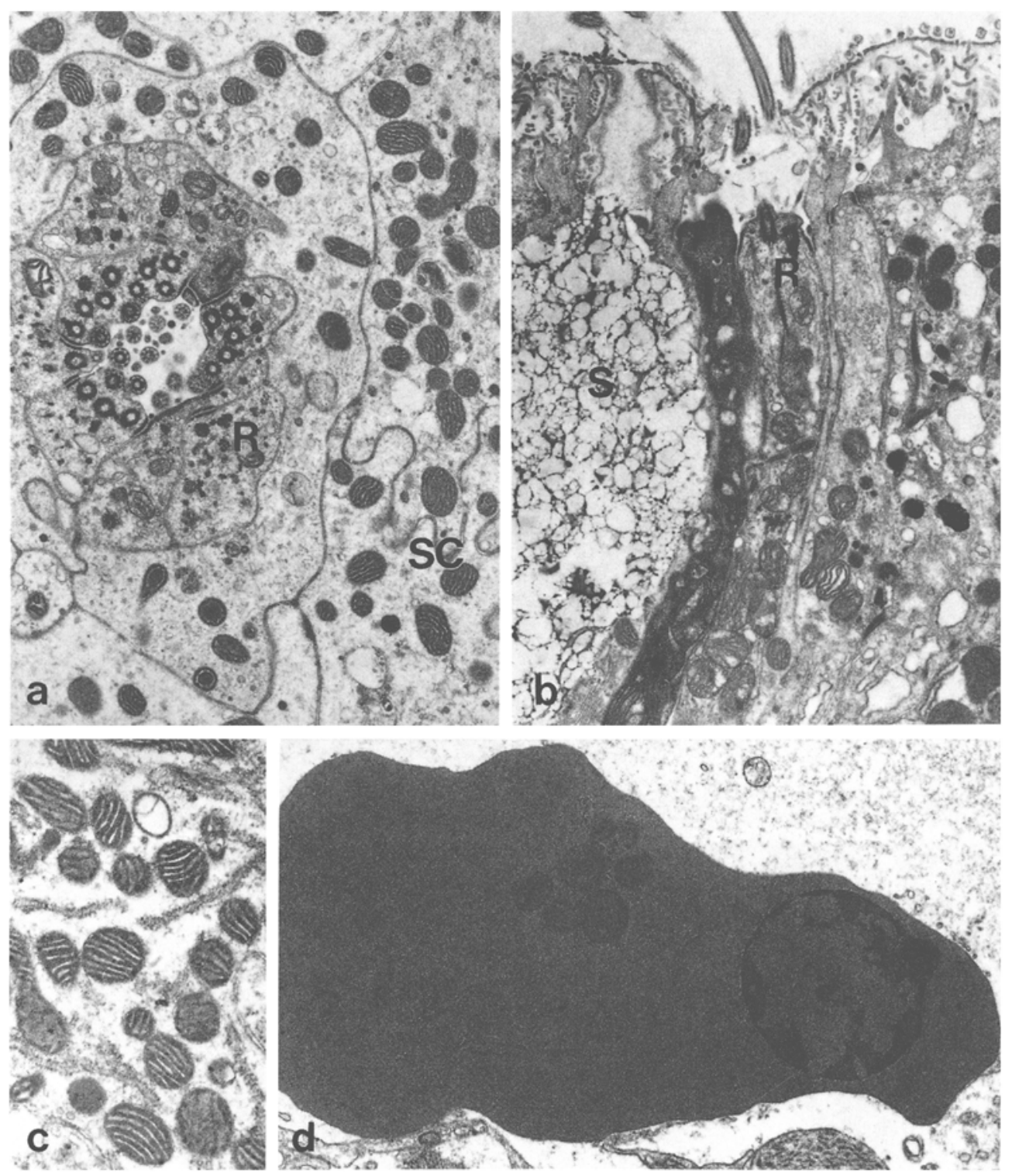

Fig. 5. Alvinella pompejana. Various cell types of feeding appendage. a cross section of receptor cells $(\mathrm{R})$ and surrounding supportive cells $(\mathrm{SC})(9500: 1) ; b$ longitudinal section of receptor cells (R) and adjacent secretory cell (S) (9500: 1); $c$ mitochondria of supportive cell (19 000: 1); $d$ blood cell (9500: 1)

very near to the external medium. These infoldings are regularly arranged, and the blood space is not lined by an epithelium of mesodermal origin. Again, this is a case of an annelid with an open blood vascular system. The epithelial cells house a dense population of mitochondria, which again differ in their ultrastructure (Fig. 3e). Secretory 
cells of the goblet cell type and groups of bipolar ciliary receptor cells occur on the gills. The basal part of the gills contain muscle cells in their core.

The gills of Amphicteis gunneri are long and smooth appendages with thick cuticle (5-7 $\mu \mathrm{m})$. At its surface, it carries epicuticular projections, which are similar to the ones described from Alvinella pompejana (Fig. 2d). The epithelium is columnar and underlain with a thick layer of muscle cells.

\section{DISCUSSION}

The present investigation has shown that the so-called gills of Alvinella pompejana and Amphicteis gunneri are so different in their ultrastructure that their function can by no means be identical. The gills of Amphicteis gunneri have a very thick cuticle and prismatic epidermis cells which are underlain with musculature. Thus, they do not fulfil the demands of respiratory epithelia which are composed of flat cells that allow gas exchange across the body surface merely by diffusion. On the other hand in the gills of Alvinella pompejana, the distance between the integumental surface and the subepidermal blood spaces can be as small a $1 \mu \mathrm{m}$. This value corresponds to extreme cases reported for other polychaetes (Storch \& Alberti, 1978). This is of the same magnitude as diffusion distances in the mammalian lung, or in fish gills.

Polychaete gills can be classified as follows:

(a) gills with true blood vessels bordered by epitheliomuscular cells.

(b) gills with partly opened vessels. The vessels are no longer tubular channels, but open out in the direction of the epidermis.

(c) gills with blood spaces directly below the surface epithelium, which are not lined by coelothelial cells.

(d) gills with blood spaces bulging deeply into the surface epithelium. Here, the greatest reduction of the distance between blood and water has been achieved. This lastmentioned type was found in Alvinella pompejana.

Furthermore, it has to be mentioned that epibiotic bacteria are absent from the gills and feeding tentacles of Alvinella pompejana. It seems that the presence of sea water does not allow their colonization. The worms generally stay inside their tubes, only their buccal part being in contact with the ambient water.

The feeding tentacles are characterized by several kinds of epidermal secretory cells. As in other marine invertebrates, these cells exhibit varied ultrastructures. Their function, however, remains to be elucidated. In Anaitides mucosa, Hausmann (1982) found many kinds of mucous cells, but could not explain their function. On sectional preparations, one cannot even see whether they, in fact, correspond to different cell types, or whether they merely represent different phases of maturation of one cell type.

In our opinion, the ER-rich cell type differs principally from the others and all other secretory cells described so far for marine invertebrates from the point of view of their upside down position. That it is in such a position raises doubt as to how the secretory products are extruded. Since they always seem to be located adjacently to a basiepithelial nerve plexus, their function may be associated with nervous activity.

Another unusual feature is the ultrastructural diversity of mitochondria in different cell types. Our results indicate that there is good reason to believe that this diversity is an expression of their equally diverse tasks. 
However, concerning the secretory cells and the mitochondria, our investigation which was based on limited material has produced more questions than anticipated, and can only be confirmed by further comparative and experimental studies.

\section{LITERATURE CITED}

Alayse-Danat, A. M., Gaill, F. \& Desbruyères, D., 1985. Preliminary studies on the relationship between the Pompeii worm, Alvinella pompejana (Polychaeta: Ampharetidae), and its epibiotic bacteria. In: Proceedings of the 19th European Marine Biology Symposium. Ed by P. E. Gibbs. University Press, Cambridge, 167-172.

Bielakoff, J., Damas, D. \& Vovelle, J. 1975. Histologie et histochimie des formations glandulaires impliqués dans l'élaboration du tube chez Lanice conchilega (Annélide Polychète). - Archs Zool. exp. gén. 116, 499-520.

Boilly-Marer, Y., 1972. Etude ultrastructurale des cirres parapodiaux de Nereidiens atoques (Annélides Polychètes). - Z. Zellforsch. mikrosk. Anat. 131, 309-327.

Desbruyères, D. \& Laubier, L., 1980. Alvinella pompejana gen. sp. nov., Ampharetidae aberrant des sources hydrothermales de la ride Est-Pacifique. - Oceanologica Acta 3, 267-274.

Desbruyères, D., Gaill, F., Laubier, L., Prieur, D. \& Rau, G. H., 1983. Unusual nutrition of the "Pompeii worm" Alvinella pompejana (polychaetous annelid) from a hydrothermal vent environment: SEM, TEM, ${ }^{13} \mathrm{C}$ and ${ }^{15} \mathrm{~N}$ evidence, - Mar. Biol. 75, 201-205.

Desbruyères, D., Gaill, F., Laubier, L. \& Fouquet, Y., 1985. Polychaetous annelids from hydrothermal vent ecosystems: an ecological overview. - Bull. biol. Soc. Wash. 6, 103-116.

Dorsett, D. A. \& Hyde, R., 1969. The fine structure of the compound sense organs on the cirri of Nereis diversicolor. $-\mathrm{Z}$. Zellforsch. mikrosk. Anat. 97, 512-527.

Fauchald, K. \& Jumars, P. A., 1979. The diet of worms: a study of polychaete feeding guilds. Oceanogr. mar. Biol. 17, 193-284.

Gaill, F. \& Bouligand, Y., 1985. Long pitch helices in invertebrate collagens. In: Biology of invertebrate and lower vertebrate collagens. Ed. by A. Bairati \& R. Garrone. Plenum Publ. Corp., London, 267-274.

Gaill, F., Halpern, S., Quintana, C. \& Desbruyères, D., 1984a. Présence intracellulaire d'arsenic et de zinc associés au soufre chez une Polychète des sources hydrothermales (Alvinella pompejana). - C. r. Acad. Sci., Paris 298, (Sér. 3), 331-336.

Gaill, F., Desbruyères, D., Prieur, D. \& Gourret, J. P., 1984 b. Mise en évidence de communautés bactériennes épibiontes du "Ver de Pompéi" (Alvinella pompejana). - C. r. Acad. Sci., Paris 298, (Sér. 3), 553-558.

Hausmann, K., 1982. Elektronenmikroskopische Untersuchungen an Anaitides mucosa (Annelida, Polychaeta). Cuticula und Cilien, Schleimzellen und Schleimextrusion. - Helgoländer Meeresunters. 35, 79-96.

Hilbig, B., 1986. Vergleichende licht- und elektronenmikroskopische Untersuchungen an Cuticula, Epidermis und Borsten einiger Eunicida (Polychaeta, Annelida). II. Epidermale Drüsen. - Zool. $\mathrm{Jb}$. (Anat. Ontogenie Tiere) 114, 371-400.

Kryvi, H., 1972: The fine structure of the ventral mucous cells of Sabella penicillum (Polychaeta). Sarsia 48, 23-32.

Laubier, L. \& Desbruyères, D., 1985. Oases of the bottom of the ocean. - Endeavour N. S. 9, 67-76.

Laubier, L., Desbruyères, D. \& Chassard-Bouchand, C., 1983. Microanalytical evidence of sulfur accumulation in a polychaete from deep-sea hydrothermal vents, - Mar. Biol. Lett. 4, 113-116.

Lawry, J. V., 1967. Structure and function of the parapodial cirri of the polynoid polychaete, Harmothoe. - Z. Zellforsch. mikrosk. Anat. 82, 345-361.

Martin, G. G., 1978. The duo-gland adhesive system of the archiannelids Protodrilus and Saccocirrus and the turbellarian Monocelis. - Zoomorphology 91, 63-75.

Menendez, A., Arias, J. L., Tolivia, D. \& Alvarez-Uria, M., 1984. Ultrastructure of gill epithelial cells of Diopatra neapolitana (Annelida, Polychaeta). - Zoomorphology 104, 304-309.

Michel, C., 1970. Sur les cellules sensorielles de la trompe de quatre annélides polychètes errantes. - Bull. Soc. zool. Fr. 95, 719-726. 
Reynolds, E. S., 1963. The use of lead citrate at high $\mathrm{pH}$ as an electron opaque stain in electron microscopy. - J. Cell Biol. 17, 208-212.

Schulte, E. \& Riehl, R., 1976. Elektronenmikroskopische Untersuchungen an den Tentakeln von Lanice conchylega (Polychaeta, Sedentaria). - Helgoländer wiss. Meeresunters. 28, 191-205.

Storch, V., 1972. Elektronenmikroskopische Untersuchungen an Rezeptoren von Anneliden (Polychaeta, Oligochaeta). - Z. mikrosk. - anat. Forsch. 85, 55-84.

Storch, V. \& Alberti, G., 1978. Ultrastructural observations on the gills of polychaetes. - Helgoländer wiss. Meeresunters. $31,310-322$.

Storch, V. \& Welsch, U., 1972. The ultrastructure of epidermal mucous cells in marine invertebrates (Nemertini, Polychaeta, Prosobranchia, Opisthobranchia). - Mar. Biol. 13, 167-175.

Vovelle, J. \& Gaill, F., 1986. Données morphologiques, histochimiques et microanalytiques sur l'élaboration du tube organominéral d'Alvinella pompejana, Polychète des sources hydrothermales, et leurs implications phylogénétiques. - Zool. Scr. 15, 33-43. 